\title{
Media Sosial sebagai Sarana Penyebaran Kearifan Lokal Adat Minangkabau dalam Pelestarian Hutan Tropis Basah Harau
}

\author{
Pasca Zenitho Nuari \\ Program Doktor Ilmu Lingkungan Jl. Pattimura No. 9 Gedung I Gobah, Pekanbaru
}

\begin{abstract}
This research was conducted in Harau District, Limahpuluh Kota Regency, West Sumatera Province which has 270,5 Ha wet tropical forest on its hill which serves as a biological source with watershed (DAS) that can be utilized by the community. Biological sources such as flowers, fern-type vegetables, medicines, and some types of freshwater fish can be consumed or economic resources for the community. The source of water is used to irrigate the fields, as a tourist attraction waterfall, and swimming pool. Wet tropical forests also serve as a home for germplasm that can be used for scientific research of herbal medicines. The threat to destruction of the wet tropical forests of Harau is primarily gambier cultivation that can cause deforestation. Further damage can be caused by the taking of ornamental plants and flowers that is biodiversity reserves. This threat to forest destruction will obviously have a negative impact because of the effects of the loss of some forest trees and the biodiversity reserves of flowers, especially in areas with large ecological and biodiversity functions. According to the authors observation of this forest damage is about 10\% (approximately $27 \mathrm{Ha}$ ) of forest area. Based on the research results it can be seen that the Harau people still use local wisdom and petitih petitih, pantun, talibun, gurindam, and tambo. Minangkabau custom in preserving wet tropical forest. The spread of local wisdom values in the past is done through generations of bakaba (oral information), custom speech, maota in lapau (chats in the shop), and surau (mosque) tradition. Socialization of local wisdom values according to the present condition is utilizing information technology/social media. In modern society, social media has a very real role as part of everyday human life, especially the younger generation. Spreading the values of local wisdom to conservation of wet tropical forest Harau through social media is considered the best to do in addition to the existing tradition. The values of local wisdom are not obsolete values that must be turned off, but can synergize with universal values and modern values. These issues can synergize with the actualization of the local philosophy of the Minangkabau community. Therefore, the dissemination of the values of Minangkabau custom local wisdom to preservation of wet tropical forest Harau can be done through social media.
\end{abstract}

Key words: social media, preservation, Harau wet tropical forest.

Hutan tropis basah dengan segala karakteristiknya merupakan daerah yang unik, sekaligus rentan terhadap aktivitas manusia di sekelilingnya. Keberadaan hutan tropis basah sebagai bagian dari sebuah ekosistem yang besar memiliki arti dan peranan penting dalam menyangga sistem kehidupan masyarakat di sekitarnya. Berbagai manfaat dapat diperoleh dari keberadaan hutan tropis basah. Hutan ini mempunyai fungsi sebagai penyedia bibit tanaman dan hewan, sumber air bagi manusia dan lingkungan, pencegah terjadinya erosi, kemampuan menyerap karbon, pemasok oksigen di udara, pengatur iklim global, dan penyedia jasa wisata.
Kelestarian hutan tropis basah Harau sangat bergantung terhadap bagaimana eksploitasi yang dilakukan oleh masyarakat di sekitarnya. Pengelolaan yang eksploitatif tanpa mengikuti kaidah-kaidah kelestarian, pastilah akan menjadikan hutan tropis basah di wilayah tersebut akan menurun kualitas maupun kuantitasnya. Dalam pelestarian hutan tropis basah, masyarakat harus ditertibkan agar bisa melakukan aktivitas dengan cermat, penuh kehati-hatian, dan terarah dalam memanfaatkan. Baik buruknya dampak pemanfaatan hutan tropis basah dalam usaha meningkatkan kesejahteraan dan kenyamanan masyarakat dengan tidak mengganggu kelestarian hutan tropis basah merupakan penerapan kearifan 
lokal dari sistem adat yang ada di daerah tersebut. Kesadaran untuk menjaga dan memelihara lingkungan hidup sesungguhnya telah lama dimiliki oleh masyarakat tradisional pedesaan. Namun seiring dengan kemajuan zaman, paradigma pembangunan berbasis kearifan lokal masyarakat sering ditinggalkan begitu saja. Akibatnya nilai-nilai sosial budaya yang dianut sekian lama di suatu masyarakat pedesaan menjadi berkurang.

Di Kecamatan Harau, Kabupaten Limahpuluh Kota, Provinsi Sumatera Barat terdapat hutan tropis basah seluas $270,5 \mathrm{Ha}$ di atas bukitnya dengan daerah aliran sungai (DAS) yang berfungsi sebagai sumber hayati dan air yang dapat dimanfaatkan penduduk sebagai sumber mata pencaharian. Sumber hayati seperti bunga-bungaan, sayur-sayuran jenis paku-pakuan, obat-obatan, dan beberapa jenis ikan air tawar dapat dikonsumsi oleh penduduk. Sumber airnya dimanfaatkan untuk mengairi sawah, sebagai objek wisata air terjun, dan kolam renang. Hutan tropis basah juga berfungsi sebagai rumah bagi plasma nutfah yang dapat dimanfaatkan untuk riset ilmiah obat-obatan herbal.

Hutan tropis basah di Kecamatan Harau memiliki berbagai spesies tanaman dataran tinggi yang dilindungi seperti: Damar (Agathis labilarderi), Suren (Toona sinensis), Ulin (Eusideroxlon zwageri) Meranti (Shorea sp), Durian (Durio zibethinus), Jambu monyet (Palagium burchi), Sumban (Palaqium gutra), Kemiri (Aleurites mollucana), Enau (Arenga pinnata), Kayukuning (Cudrania sp), Kulitmanis (Cinnamomun burmanii), dan Kemenyan (Styrac sp). Menurut pengamatan penulis dari tahun ke tahun jumlah tanamannya menyusut yang mengakibatkan hutan tropis basah di lereng bukit menjadi gundul karena pembukaan lahan menjadi kebun gambir dan sebagian ditumbuhi semak belukar terutama bahagian yang berlawanan arah dengan objek wisata air terjun. Diduga ada pelanggaran bahkan pengabaian terhadap nilai-nilai tradisional (kearifan lokal adat Minangkabau) yang dipatuhi masyarakat selama ini. Fenomena ini diperkuat oleh temuan Dinas Pariwisata Sumatera Barat yang melaporkan bahwa hutan tropis basah saat ini mengalami kerusakan.
Alam dengan segala dinamika dan bentuknya sangat berarti bagi masyarakat Minangkabau. Oleh karena begitu berartinya, masyarakat Minangkabau menamakan tanah leluhurnya dengan alam, yaitu Alam Minangkabau. Alam bagi masyarakat Minangkabau mengandung makna yang tidak terhingga. Alam adalah segala-galanya, bukan hanya sebagai tempat lahir dan tempat mati, tempat hidup dan berkembang, melainkan juga mempunyai makna filosofis yang dalam, yaitu alam takambang jadi guru (alam terkembang jadi guru). Oleh karena itu, ajaran dan pandangan hidup mereka yang dikonfigurasikan dalam pepatah, petitih, pituah, pantun, serta lain-lainnya selalu mengambil perumpamaan kepada alam (Gani, 2009).

Kearifan lokal merupakan salah satu warisan budaya yang ada di masyarakat dan secara turun-menurun dilaksanakan oleh masyarakat yang bersangkutan. Kearifan lokal tersebut umumnya berisi ajaran untuk memelihara dan memanfaatkan sumberdaya alam (hutan, tanah, dan air) secara berkelanjutan. Dari sisi lingkungan hidup keberadaan kearifan lokal sangat menguntungkan karena secara langsung atau pun tidak langsung sangat membantu dalam memelihara lingkungan serta mencegah terjadinya kerusakan lingkungan (Lampe, 2006). Penelitian ini bertujuan untuk mengevaluasi penyebaran nilai-nilai kearifan lokal adat Minangkabau pada masa lalu dan sekarang terhadap pelestarian hutan tropis basah di Kecamatan Harau.

\section{BAHAN DAN METODE}

Penelitian ini dilakukan di Kecamatan Harau yang mempunyai hutan tropis basah seluas 270, 5 di atas bukitnya yang merupakan Cagar Alam, air terjun yang dapat mengairi sawah-sawah di sekitar lembah dan objek wisata air terjun serta kolam renang seluas 27,5 ha (Taman Wisata Alam). Secara administratif hutan tropis basah tersebut berada di Kabupaten Limapuluh Kota, Provinsi Sumatera Barat. Pemilihan lokasi ini didasarkan pada kenyataan bahwa masyarakatnya masih menggunakan kearifan lokal dan petatah petitih adat Minangkabau dalam melestarikan hutan tropis basah. 
Data yang dikumpulkan terdiri dua jenis yaitu data primer dan data sekunder. Pengumpulan data primer dilakukan melalui pengumpulan jawaban yang diberikan oleh responden terhadap pertanyaan yang terdapat dikuisioner. Secara khusus cara yang digunakan dalam pengumpulan data antara lain wawancara mendalam (indepth interview) melalui responden kunci yaitu: Ketua Adat dan Penghulu/Datuk-datuk yang diperkirakan benarbenar mengetahui dan memberikan informasi mengenai penyebaran kearifan lokal adat Minangkabau di Kecamatan Harau. Selain itu, juga dilakukan observasi terhadap objek penelitian yaitu hal-hal yang berkenaan dengan pelestarian hutan tropis basah. Pengumpulan data sekunder (iklim, hidrologi, flora, fauna, dan perubahan ekologi hutan tropis basah) dilakukan untuk mendukung penelitian ini melalui studi pustaka baik berupa hasil-hasil penelitian terdahulu maupun tulisan-tulisan lain, dan laporan-laporan instansi yang terkait dengan permasalahan yang diteliti.

Analisis data menggunakan analisis domain semantik (Milles dan Huberman, 2007). Analisis domain semantik merupakan penyelidikan terhadap penyebaran dan pelaksanaan kearifan lokal masyarakat, dan akibatnya terhadap pelestarian hutan tropis basah. Jadi analisis domain semantik dilakukan untuk memperoleh gambaran yang menyeluruh tentang situasi yang diteliti.

\section{HASIL}

\section{Hutan Tropis Basah Kecamatan Harau}

Ciri-ciri hutan tropis basah Harau adalah curah hujannya tinggi rata-rata 3000-5000 $\mathrm{mm} /$ tahun. Ketinggian 400-850 m dpl. Pohonpohon utama di hutan ini (diperkirakan 70\% berdiameter menengah-kecil dan $30 \%$ berdiameter besar), memiliki ketinggian antara 20-40 m dengan cabang pohon berdaun lebat dan lebar serta selalu hijau sepanjang tahun, mendapat sinar matahari yang cukup walaupun sinar matahari tersebut tidak mampu menembus dasar hutan, dan mempunyai iklim mikro (suhu rata-rata $25{ }^{\circ} \mathrm{C}$ ) di lingkungan sekitar permukaan tanah atau di bawah kanopi (daun pada pohon-pohon besar yang membentuk tudung).
Berbagai jenis hewan ada di sini di antaranya: monyet ekor panjang (Macaca fascirulatis). Ada pula siamang (Hylobatessyndactylus), dan simpai (Presbytis melalopos). Hewan yang jang dilindungi di sini adalah harimau Sumatera (Panthera tigris sumatrensis), beruang (Helarctos malayanus), tapir (Tapirus indicus), kambing hutan (Capriconis sumatrensis), dan landak (Proechidna bruijnii). Ada 19 spesies burung yang juga dilindungi, di antaranya, burung kuau (Argusianus argus) dan enggang (Anthrococeros sp).

Hutan tropis basah Harau sesungguhnya mempunyai manfaat yang sangat besar bagi kehidupan masyarakat di sekitarnya. Manfaatnya antara lain adalah pencegahan terhadap erosi, mencegah kekeringan dengan menyediakan sumber air yang lebih dari cukup bagi kehidupan di sekitarnya, pelindung dari badai, penghasil kayu, dan penjaga keseimbangan iklim. Selain itu, hutan tropis basah juga berperan dalam menyerap gas karbondioksia $(\mathrm{CO} 2)$ yang berada di atmosfer bumi yang kemudian akan diolah dan dikeluarkan sebagai oksigen untuk pernafasan manusia dan hewan. Di samping itu hutan tropis basah berperan sebagai cadangan utama keanekagaraman hayati, sebagai komponen penting dalam siklus karbon global maupun sistem hidrologi, dan punya nilai-nilai rekreasi, keindahan, pendidikan, dan penelitian.

Perubahan iklim sudah menjadi perbincangan umum dalan percakapan para pemerhati lingkungan di dunia ini, meski demikian ternyata kejadian alam ini tidak terlalu banyak dipahami secara tepat oleh masyarakat karena memang cukup rumit sehingga terjadi kesalahpahaman atau kesulitan membedakan antara perubahan iklim dengan variasi iklim yang sering terjadi secara tiba-tiba dan ekstrem yang membawa dampak seketika. Perubahan iklim tersebut dipicu oleh kegiatan manusia yang berkaitan dengan penggunaan Bahan Bakar Fosil (BBF) dan kegiatan alih guna lahan seperti perladangan.

Ancaman kerusakan hutan tropis basah Harau yang utama adalah perladangan gambir yang dapat menyebabkan gundulnya hutan. Selanjutnya kerusakan bisa disebabkan pengambilan tanaman hias dan bunga-bungaan yang merupakan cadangan keanekaragaraman 
hayati. Ancaman kerusakan hutan ini jelas akan menimbulkan dampak negatif karena adanya efek dari hilangnya sebagian pohon hutan dan cadangan keanekaragaman hayati bungabungaan, terutama pada kawasan-kawasan yang mempunyai nilai fungsi ekologis dan keanekaragaman hayati besar. Menurut pengamatan penulis kerusakan hutan ini sekitar 10\% (lebih kurang $27 \mathrm{Ha}$ ) dari kawasan hutan cagar alam.

\section{Manfaat Hutan Tropis Basah}

Hutan tropis basah Harau sesungguhnya mempunyai manfaat yang sangat besar bagi kehidupan masyarakat di sekitarnya. Manfaatnya antara lain adalah pencegahan terhadap erosi, mencegah kekeringan dengan menyediakan sumber air yang lebih dari cukup bagi kehidupan di sekitarnya, pelindung dari badai, penghasil kayu, dan penjaga keseimbangan iklim. Selain itu, hutan tropis basah juga berperan dalam menyerap gas karbondioksia $(\mathrm{CO} 2)$ yang berada di atmosfer bumi yang kemudian akan diolah dan dikeluarkan sebagai oksigen untuk pernafasan manusia dan hewan. Di samping itu hutan tropis basah berperan sebagai cadangan utama keanekagaraman hayati, sebagai komponen penting dalam siklus karbon global maupun sistem hidrologi, dan punya nilai-nilai rekreasi, keindahan, pendidikan, dan penelitian.

Perubahan iklim sudah menjadi perbincangan umum dalan percakapan para pemerhati lingkungan di dunia ini, meski demikian ternyata kejadian alam ini tidak terlalu banyak dipahami secara tepat oleh masyarakat karena memang cukup rumit sehingga terjadi kesalahpahaman atau kesulitan membedakan antara perubahan iklim dengan variasi iklim yang sering terjadi secara tiba-tiba dan ekstrem yang membawa dampak seketika. Perubahan iklim tersebut dipicu oleh kegiatan manusia yang berkaitan dengan penggunaan Bahan Bakar Fosil (BBF) dan kegiatan alih guna lahan seperti perladangan.

Ancaman kerusakan hutan tropis basah Harau yang utama adalah perladangan gambir yang dapat menyebabkan gundulnya hutan. Selanjutnya kerusakan bisa disebabkan pengambilan tanaman hias dan bunga-bungaan yang merupakan cadangan keanekaragaraman hayati. Ancaman kerusakan hutan ini jelas akan menimbulkan dampak negatif karena adanya efek dari hilangnya sebagian pohon hutan dan cadangan keanekaragaman hayati bungabungaan, terutama pada kawasan-kawasan yang mempunyai nilai fungsi ekologis dan keanekaragaman hayati besar. Menurut pengamatan penulis kerusakan hutan ini sekitar 10\% (lebih kurang $27 \mathrm{Ha}$ ) dari kawasan hutan cagar alam.

\section{Hidrologi}

Hutan tropis basah Harau membantu menjaga peredaran air. Peredaran air, juga dikenal dengan peredaran hidrologi, menggambarkan pergerakan berkelanjutan dari air di atas dan di bawah permukaan bumi. Peran hutan tropis basah dalam peredaran air ini adalah untuk menambah air ke atmosfer melalui proses transpirasi (melepas air dari daundaunnya). Pengendalian aliran (hasil air), distribusi sumberdaya air selalu berhubungan dengan ruang dan waktu. Akhir-akhir ini hutan tropis basah lebih sering dihadapkan pada suatu keadaan berlebihan air pada musim hujan dan kekurangan air di musim kemarau sehingga menyebabkan air terjun di Harau mengering. Sampai saat ini masih dipercayai bahwa hutan yang baik (tidak mengalami kerusakan) mampu mengendalikan daur air artinya hutan yang baik dapat menyimpan air selama musim hujan dan melepaskannya di musim kemarau. Kepercayaan ini didasarkan atas masih melekatnya di hati masyarakat bukti-bukti bahwa banyak sumber-sumber air dari dalam kawasan hutan yang baik tetap mengalir pada musim kemarau.

\section{Kearifan Lokal Adat Minangkabau}

Kearifan lokal adat Minangkabau adalah suatu kekayaan budaya lokal yang mengandung kebijaksanaan hidup, pandangan hidup yang mengakomodasi kebijakan dan kearifan hidup. Secara lebih spesifik, kearifan lokal merupakan perpaduan antara nilai-nilai suci firman Tuhan dan berbagai nilai yang ada. Kearifan lokal terbentuk sebagai keunggulan budaya masyarakat setempat. Kearifan lokal merupakan produk budaya masa lalu yang patut secara terus-menerus dijadikan pegangan hidup. Meskipun bernilai lokal tetapi nilai yang terkandung di dalamnya dianggap sangat universal. 
Kalau kita berbicara Minangkabau, maka kearifan lokal adat Minangkabau adalah nilai-nilai yang terkandung dalam filosofi: Adaik Basandi Syarak, Syarak Basandi Kitabullah, Syarak Mangato Adaik Mamakai, Alam Takambang Jadi Guru. Minangkabau adalah ranah yang kaya akan petatah petitih yang dipersembahkan melalui tambo. Berarti segala aktivitas masyarakat Minangkabau dalam kehidupan sehari-hari haruslah sesuai dengan aturan adat yang berlaku dan seiring sejalan dengan akidah Agama Islam. Adat merupakan aturan atau norma dalam pergaulan antar masyarakat sehari-hari, begitu juga dengan Kitabullah yang berarti Alqur'an dan menjadi pedoman hidup bagi umat Islam. Sehingga, dengan adanya pepatah tersebut sudah jelas bahwa orang Minangkabau asli menganut agama Islam. Berikutnya adalah ungkapan "Alam takambang jadi Guru", maksudnya adalah orang Minangkabau itu harus belajar dari alam, harus bisa memanfaatkan apa saja yang ada di alam untuk kelangsungan hidupnya, karena alam merupakan rahmat atau anugerah yang diberikan oleh Allah SWT untuk dimanfaatkan semaksimal mungkin bagi manusia yang mau berusaha dan berikhtiar kepadaNya.

Di Propinsi Sumatera Barat ada Lembaga Kerapatan Adat Alam Minangkabau (LKAAM) yang bukan merupakan organisasi adat Minangkabau, tetapi merupakan organisasi ninik mamak Minangkabau yang berada di Propinsi, Kabupaten dan Kecamatan. Sebagai organisasi niniak mamak tugasnya adalah menerapkan dan menyebarluaskan Adaik Basandi Syarak dan Syarak Basandi Kitabullah.

Arus globalisasi selalu ditandai dengan memberikan dampak positif dan negatif terhadap kearifan lokal yang sudah ada semenjak zaman dahulu. Derasnya arus globalisasi ini tentu juga mempunyai pengaruh terhadap pengelolaan hutan, tanah, dan air. Diantara dampak negatif globalisasi itu antara lain terjadinya pergeseran nilai-nilai, dengan semakin berkurangnya pemahaman tentang kearifan lokal yang ada, orang Minangkabau tidak bangga lagi dengan adat dan budaya sendiri, tetapi senang dan punya percaya diri dengan budaya asing. Oleh karena itu kekhawatiran akan hilangnya nilai filosofi Adat basandi syarak, Syarak basandi kitabullah
(Adat bersendi aturan, Aturan bersendi Al Quran) akan semakin beralasan, dan bukan tidak mungkin adat akan tinggal slogan serta hanya tercatat dalam lembaran sejarah, bila kekhawatiran itu menjadi kenyataan, adalah sesuatu yang sulit untuk dibantah. Dalam kondisi seperti inilah peran LKAAM menjadi lebih penting untuk memberikan pelurusan dan pemahaman nilai-nilai kearifan lokal yang ada terutama kepada generasi muda.

\section{Penyebaran Kearifan Lokal Adat Minangkabau}

Tujuan hidup bagi orang Minangkabau adalah untuk berbuat jasa. Kato pusako orang Minangkabau mengatakan bahwa "hiduik bajaso, mati bapusako". Jadi orang Minangkabau memberikan arti dan harga yang tinggi terhadap hidup. Untuk analogi terhadap alam, maka pribahasa yang dikemukakan adalah:

Gajah mati maninggakan gadieng (Gajah mati meninggalkan gading)

Harimau mati maninggakan balang (Harimau

Mati meninggalkan belang)

Manusia mati maninggakan namo (Manusia mati meninggalkan nama)

Pengertiannya, bahwa orang Minangkabau itu hidupnya jangan seperti hidup hewan yang tidak memikirkan generasi selanjutnya, dengan segala yang akan ditinggalkan setelah mati. Oleh sebab itu orang Minangkabau bekerja keras untuk dapat meninggalkan, mempusakakan sesuatu bagi anak kemenakan dan masyarakatnya. Mempusakakan bukan maksudnya hanya dibidang materi saja, tetapi juga nilai-nilai adatnya.

Selanjutnya mereka terus mencari sesuatu, sesuatu yang "Indak Lakang dek Paneh, Indak Lapuak dek Hujan" untuk diwariskan kepada anak cucu. Alam menunjukkan: Yang Tidak Lekang oleh Panas, Tidak Lapuk oleh Hujan itu hanyalah sesuatu yang tumbuh, sesuatu yang berkembang, itulah kato. Kato, kata-kata lisan, bukan tulisan, di atas batu sekalipun. Nenek moyang orang Minangkabau memilih cara "kato" untuk meninggalkan "jejak". Kata-kata lisan tersebut harus menyebar ke seluruh orang Minangkabau. Menyebar dan terekam dalam pikiran, keseharian, angan-angan, bahkan 
mimpi-mimpi mereka. Kata-kata itu harus terpahat/terpatri di hati, harus indah, lahirlah petatah/petitih, pantun, pidato pasambahan, gurindam, petuah, mamangan, berbagai bentuk sastra lisan.

Sastra lisan itu harus tersebar, diperlukan wadah untuk menyebarkannya. Orang Minangkabau menciptakan berbagai arena untuk menyebarkan kata-kata lisan tersebut. Arena itu melembaga di masyarakat dan sebagian besar masih ada bahkan berkembang sampai sekarang. Tradisi lisan itu berlangsung dalam beberapa kegiatan atau lembaga sosial:

1. Tradisi kaba, bakaba, serta segala variasinya, seperti sijobang, dendang, rabab, dan salawat dulang.

2. Tradisi pasambahan, panitahan, pidato adat, kato-bajawek-gayuang-basambuik, serta segala variasinya, yang terus berlangsung sampai sekarang, sepanjang zaman pada setiap upacara adat.

3. Tradisi maota di lapau (ngobrol di kedai).

4. Tradisi surau (Langgar).

Pengaruh empat lembaga penyebaran konfigurasi kearifan lokal adat Minangkabau menyebabkan siapapun orang Minangkabau pernah merekam bagian-bagian tertentu dalam ingatannya. Salah satu lembaga tersebut pasti pernah meninggalkan jejak dalam ingatan orang Minangkabau. Siapapun orang Minangkabau tentu pernah mendengar salah satunya: kaba, carito, pepatah-petitih, pituah, pantun, talibun, gurindam, dan tambo, di mana pun dia lahir atau dibesarkan. Di rantau sejauh apa pun, tentu ada jejak nilai dari kearifan lokal adat Minangkabau dalam ingatannya, walau hanya sepotong kecil petuah, atau sebuah istilah, seperti: nan baiak budi (yang baik budi), nan indah baso (yang indah bahasa), pangulu (penghulu), niniak mamak (ninik mamak), cadiak pandai/manti (cendekiawan), dan dubalang (asisten penghulu).

Kemajuan ilmu pengetahuan yang dapat dianggap sebagai "Peta Alam Terkembang" telah menambah pemahaman manusia akan bagaimana bekerjanya alam semesta ini, sehingga "manusia mampu menguasai alam". Penerapan ilmu dalam berbagai teknologi telah meningkatkan kemampuan manusia untuk memanfaatkan alam sesuai berbagai keinginan manusia. Pasa jalan dek batampuah, lanca kaji dek ba ulang. Pengetahuan didapat dengan dipelajari, untuk lebih praktis harus diamalkan dalam kehidupan. Pandai karano batanyo, tahu karano baguru. Pengetahuan diperdapat karena belajar, pendidikan dan banyak bertanya kepada orang yang tahu. Sadang baguru kapalang aja, lai bak bungo kambang tak jadi. Kunun kok dapek dek mandanga, tidak didalam dihalusi. Setiap menuntut pengetahuan jangan putus ditengah, dan kurang manfaatnya dengan mendengar saja, kalau dibandingkan dengan belajar sesungguhnya. Sabab karano dek baitu, tumbuahlah niaik dalam hati, nak manuruik tambo nan dahulu sajarah adat nan usali. Kalau ajaran adat telah dapat dipahami kemana masyarakat hendak dibawa oleh ajaran adat itu maka akan timbullah hasrat untuk mendalaminya. Satinggi-tinggi malantiang, mambubuang ka awang-awang, suruiknyo katanah juo. Sahabih dahan jo rantiang, dikubak dikulik batang, tareh panguba barunyo nyato. Adat Minangkabau tidak akan bisa dipahami secara baik, apalagi untuk dihayati dan diamalkan tanpa mendalami sungguh-sungguh. Baribu nan tidak lipuah, jajak nan indak hilang. Satu ajaran yang tetap berkesan, yang diterima turun temurun.

\section{PEMBAHASAN}

\section{Hutan Tropis Basah Kecamatan Harau}

Hutan tropis basah Harau juga berfungsi sebagai Cagar Alam yang merupakan salah satu kawasan lindung yang sangat penting, terutama sebagai sistem penyangga kehidupan, budidaya keanekaragaman jenis tumbuhan dan hewan dan pemanfaatan secara lestari sumberdaya alam hayati dan ekosistemnya. Cagar alam adalah suatu kawasan suaka alam karena keadaan alamnya mempunyai kekhasan tumbuhan, binatang, dan ekosistemnya atau ekosistem tertentu yang perlu dilindungi dan perkembangannya berlangsung secara alami. Sesuai dengan sejarah dan karakteristik kawasan Cagar Alam Harau, ke depan perlu dilakukan peran serta masyarakat dalam pengelolaan kawasan ini, dengan memberikan akses yang lebih baik bagi masyarakat untuk ikut berperan serta dalam pemanfaatan potensi kawasan.

Kondisi tanahnya yang relatif tergenang oleh air, maka hewan yang banyak terdapat di hutan ini adalah primata-primata yang pandai memanjat seperti monyet, simpanse, dan 
siamang. Tanpa disadari, hutan hujan tropis adalah surga bagi tumbuhan dan hewan liar, juga menjadi tempat berlindung bagi satwa yang terancam punah. Bahkan, beberapa hewan liar hanya dapat bertahan hidup di hutan tropis basah ini yang merupakan habitat aslinya. Hasil penelitian Sari et al (2012) menyatakan bahwa jumlah spesies burungnya di Kawasan Cagar Alam Harau lebih sedikit apabila dibandingkan dengan kawasan lain yang hampir sama tipe habitatnya yaitu Cagar Alam Lembah Anai dan Cagar Alam Rimbo Panti. Hal ini disebabkan ekosistem hutan alami sudah terganggu akibat aktivitas manusia yaitu sebagian hutan yang dijadikan perladangan.

\section{Manfaat Hutan Tropis Basah}

Kawasan hutan tropis basah Harau yang rusak sebagian besar merupakan wilayah tangkapan air hutan tropis basah. Akibat dari kejadian ini tidak saja hilangnya suatu kawasan hutan yang tadinya dapat mendukung kehidupan masyarakat dalam berbagai aspek misal kebutuhan akan air, oksigen, kenyamanan (iklim mikro), keindahan (wisata), penghasilan (hasil hutan non kayu dan kayu), penyerapan carbon (carbon sink), pangan, dan obat-obatan, akan tetapi juga hilang keaneragamanhayati titipan generasi mendatang. MacKinnon, et al (1990) dalam Salampessy (2010) menyatakan bahwa ada di beberapa kawasan hutan lindung interaksi antar masyarakat lokal dengan sumberdaya alam masih sangat kuat dan cenderung negatif sehingga menyebabkan kerusakan hutan. Sebaliknya di beberapa lokasi, pola interaksi yang terjalin memberikan kecenderungan positif terhadap kelestarian hutan.

Hutan dan pohon merupakan urat nadi kehidupan yang melindungi tanah, penyedia nutrisi dan energi terbarukan bagi ratusan juta orang. Tanpa jasa ini, sistem pangan akan sangat rentan; manusia tidak mampu, terutama mengalami kekurangan kebutuhan mendasar penghidupannya. Hutan juga berfungsi sebagai perlindungan terhadap efek emisi besar-besaran dari penggunaan bahan bakar fosil. Berarti manusia memerlukan hutan jika ingin bertahan hidup. Chanan (2011) mengemukakan bahwa pemanfaatan hutan yang tidak diimbangi oleh usaha pemeliharaan dan perawatan akan mengakibatkan kerusakan hutan sekaligus kerugian bagi manusia, sehingga diperlukan usaha nyata yang berkesinambungan dalam memperbaiki pengelolaan hutan untuk menjamin kelestarian hutan dimasa yang akan datang. Kerusakan hutan juga berdampak pada perubahan iklim global hingga terjadi pemanasan bumi atau yang sering disebut dengan istilah global warming. Salah satu manfaat seperti yang diutarakan di atas, bahwa hutan mempunyai manfaat konservasi iklim sebagai tempat penyimpanan dan penyerapan karbon. Menurut Hairiah dan Subekti (1997) dalam Chanan (2011) juga menerangkan bahwa tumbuhan hutan tropis basah alami menyimpan karbon tertinggi bila dibandingkan dengan tumbuhan lahan pertanian, karena tumbuhan di hutan memiliki tajuk yang lebar dan tegakan yang tinggi, tegakan tersebut memerlukan sinar matahari, air, hara dan karbon untuk kelangsungan hidupnya

\section{Hidrologi}

Hutan di atas dan lereng bukit diharapkan mampu menyediakan manfaat lingkungan yang amat besar bagi kehidupan masyarakat antara lain jasa peredaman terhadap banjir dan erosi serta pengendalian air. Joshi et al (2004) dalam Noordwijk et al (2004) menyampaikan bahwa masyarakat mempunyai pengetahuan dan kearifan lokal yang memadai (paling tidak secara kualitatif) tentang gejala alam di sekitarnya seperti curah hujan, aliran air permukaan, banjir, dan erosi, akan tetapi mereka masih kurang memahami konsep transpirasi.

Siswadi et al (2013) mengemukakan bahwa kearifan lokal dapat dipakai dan diterapkan sebagai pedoman sikap dan perilaku dalam melestarikan mata air, dalam berbagai kegiatan fisik dan ritual, rutin maupun insidentil. Atas dasar manfaat, masyarakat bersemangat untuk mempertahankan dan melestarikan tradisi yang dimilikinya. Untuk melestarikan debit air, tidak hanya dengan pemeliharaan tradisi yang ada, akan tetapi diperlukan pengelolaan hutan secara baik di sekitar mata air dan di daerah atasnya. Asrianny et al (2012) menyatakan bahwa sesuai dengan adat dan kebiasaan yang dimiliki oleh masyarakat di Kecamatan Alu Polman Sulawesi Barat dalam mengelola hutan terdapat kegiatan yang dilarang dilakukan karena dapat merusak fungsi hutan yaitu sebagai sumber air yang dapat menyebabkan kelestarian lingkungan terganggu. Larangan-larangan tersebut yaitu 
larangan memanfaatkan lahan dan menebang kayu dalam kawasan pangngale piparakkeang (hutan larangan). Larangan ini mengandung makna untuk mempertahankan kelestarian hutan dan sebagai sumber air untuk berbagai kebutuhan masyarakat. Apabila hutan tersebut terganggu dan berubah fungsinya maka kesejahteraan masyarakat juga akan terancam. Larangan tersebut juga mengandung makna untuk mencegah banjir dan tanah longsor. Selain itu, kerusakan hutan ini juga berarti merusak ekosistem yang ada di dalamnya sehingga hutan tersebut tidak dapat lagi tumbuh menjadi habitat bagi tumbuh- tumbuhan dan hewan.

\section{Kearifan Lokal Adat Minangkabau}

Perbedaan sosialisasi nilai-nilai kearifan lokal secara tradisional dan yang ideal menurut kondisi sekarang adalah memanfaatkan teknologi informasi/media sosial. Saat ini seperti kita ketahui bersama perkembangan teknologi informasi/media sosial berjalan dengan pesat. Dalam masyarakat modern, media sosial mempunyai peran yang sangat nyata sebagai bagian dari kehidupan manusia seharihari. Selain itu, ketertarikan individu atau masyarakat yang tinggi terhadap program komunikasi melalui media sosial seperti surat kabar, majalah, radio, televisi, film dan internet menjadikan setiap saat individu atau masyarakat tidak terlepas dari peran media sosial. Penyebaran nilai-nilai kearifan lokal melalui media sosial dianggap paling baik untuk dilakukan di samping tradisi yang sudah ada. Media sosial berperan memperlihatkan kepada masyarakat/khalayak tentang bagaimana seharusnya mereka bertindak dan apa yang diharapkan mereka dalam pelestarian hutan tropis basah Harau.

Ketua adat, penghulu, dubalang, manti, dan mamak Kecamatan Harau dapat berperan aktif di media sosial, ini adalah cara mudah yang dapat dilakukan untuk melestarikan hutan tropis basah dan memerangi perubahan iklim. Sekarang ini pengguna media sosial sudah banyak dan Indonesia menjadi salah satu negara dengan pengguna terbesar di dunia. Ajakan, menyampaikan tips penting lingkungan, pesan petatah petitih, pantun, talibun, tambo, dan gurindam melalui media sosial merupakan salah satu cara yang ampuh untuk mengajak masyarakat untuk sadar dengan bahaya merusak hutan dan perubahan iklim. Isu kerusakan hutan tropis basah di Harau dan perubahan iklim yang awalnya terasa berat untuk disebarluaskan menjadi lebih ringan dan mudah dicerna setelah masyarakat memahami tentang hubungan kerusakan hutan dan perubahan iklim. Berbagai pengalaman, informasi/pesan, dan ide-ide cemerlang dapat dilakukan ketua adat, penghulu, dubalang, manti, mamak dan masyarakat/khalayak untuk mengatasi masalah tersebut.

Masyarakat kita terutama generasi muda belakangan ini dihadapkan pada situasi sulit untuk tetap mempertahankan budaya lokal atau menerima budaya global. Masyarakat pada saat ini seolah terbentuk dari proses perbenturan dan pergulatan antara mewarisi yang lokal atau menerima yang global. Proses globalisasi yang mendera hampir seluruh kehidupan manusia dan budaya, kini saatnya bagi pemangku adat untuk menegaskan identitas masyarakat dengan kearifan lokal adat Minangkabau. Penegasan identitas kearifan lokal adat Minangkabau tersebut tetap memainkan peran vitalnya untuk membangun masyarakat lokal di tengah peradaban global.

Globalisasi melalui kecanggihan teknologi informasi memang membawa beragam akibat, terutama generasi muda ke depan dikhawatirkan tidak memahami nilai-nilai kearifan lokal adat Minangkabau yang sudah menjadi tradisi selama ini. Melalui teknologi informasi berbagai arus informasi begitu lancar untuk keluar masuk dalam ruang-ruang privat kita. Ruang masyarakat Minangkabau yang selama ini menjadi ruang steril dari persentuhan-persentuhan budaya asing, secara tidak disadari menjadi tempat paling nyaman bagi tersemainya persentuhan budaya itu. Generasi muda Minangkabau sering mengemukakan bahwa arus globalisasi adalah kondisi yang tidak bisa ditolak kehadirannya. Oleh sebab itu peran media sosial harus dikontrol oleh LKAAM. Hasil analisis domain semantik tentang sosialisasi nilai-nilai kearifan lokal adat Minangkabau secara tradisional dan yang ideal menurut kondisi sekarang dapat dilihat pada Gambar 1.

Tarik menarik antara mempertahankan budaya lokal dan menerima globalitas akhirnya membawa kita untuk merefleksi ulang lokalitas. 
Bukan dalam rangka untuk mengistirahatkan fungsinya sebagai identitas lokal, melainkan untuk menguatkan identitas lokal yang bertaut dengan globalitas. Pertautan itu diharapkan melahirkan sikap mempertahankan tradisi dalam kondisi global atau menjadi global tanpa harus meninggalkan kepentingan lokal. Masyarakat di Kecamatan Harau diibaratkan sebagai masyarakat yang ketika nilai-nilai lama belum tertanam secara kokoh karena pengaruh penjajahan Belanda harus dihadapkan untuk menerima nilai baru yang meski belum jelas bentuk dan sifatnya. Ibarat sebuah luka, ketika luka lama akibat penjajahan belum sembuh benar, kini dihadapkan oleh luka baru akibat pengaruh globalisasi

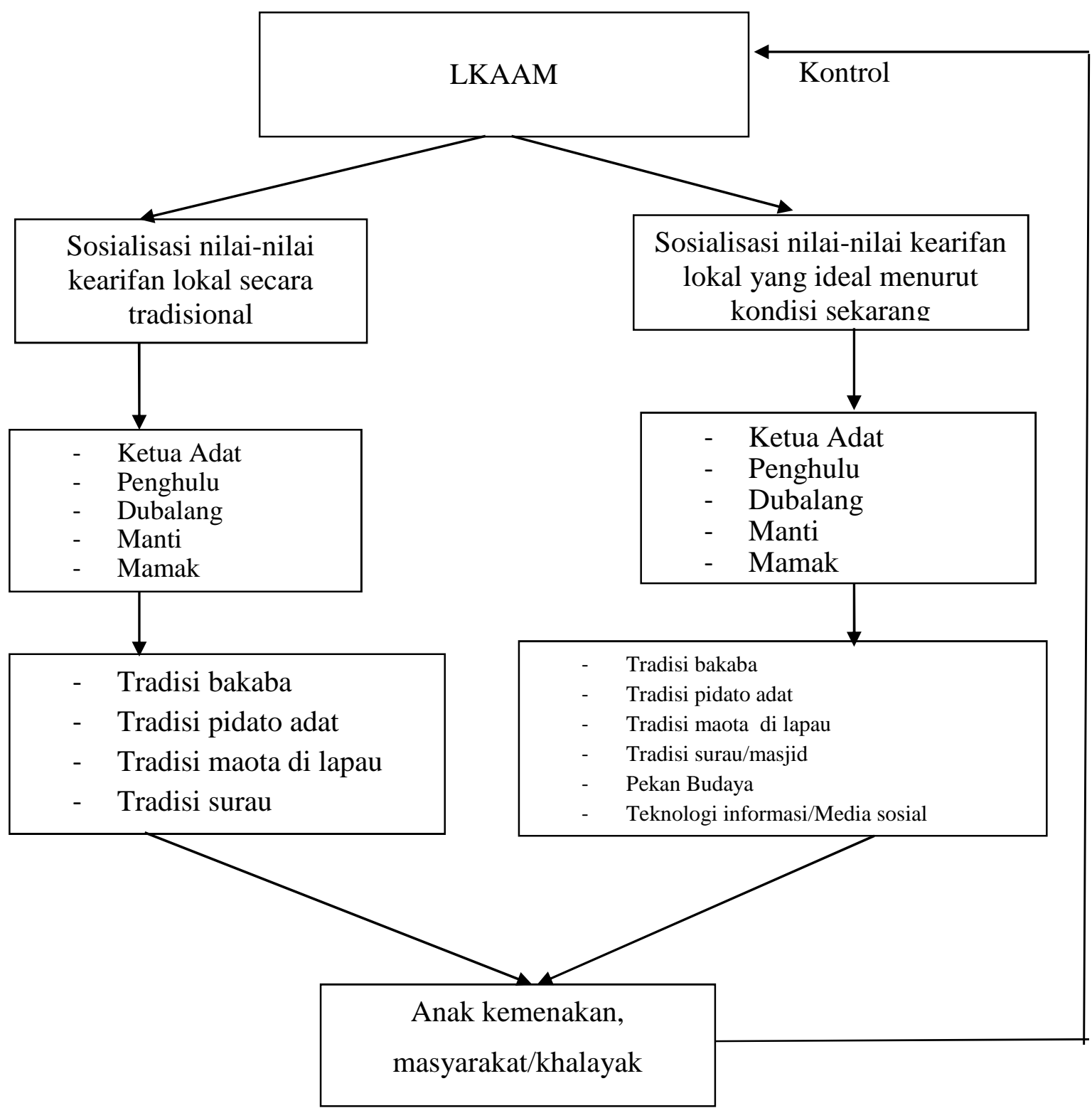

Gambar 1. Sosialisasi nilai-nilai kearifan lokal adat Minangkabau secara tradisional dan yang ideal menurut kondisi sekarang.

Kemudian hal yang tidak kalah pentingnya dalam menghadapi globalisasi budaya adalah nilai-nilai kearifan lokal bukanlah nilai usang yang harus dimatikan, tetapi dapat bersinergi dengan nilai-nilai universal dan nilai-nilai modern yang dibawa globalisasi. Isu-isu tersebut dapat bersinergi dengan aktualisasi dari filosofi lokal yang dimiliki masyarakat Minangkabau. Oleh karena itu globalisasi yang tidak terhindarkan harus diantisipasi dengan penyebaran nilai-nilai kearifan lokal adat Minangkabau dengan 
memanfaatkan teknologi informasi/media sosial. Imran (2013) mengemukakan bahwa bahwa media sosial dapat digunakan sebagai pelengkap media konvensional.

\section{SIMPULAN}

Penyebaran nilai-nilai kearifan lokal pada masa lalu dilakukan turun temurun melalui tradisi bakaba, pasambahan, maota di lapau, dan surau. Sosialisasi nilai-nilai kearifan lokal yang ideal menurut kondisi sekarang adalah memanfaatkan teknologi informasi/media sosial. Dalam masyarakat modern, media sosial mempunyai peran yang sangat nyata sebagai bagian dari kehidupan manusia seharihari. Penyebaran nilai-nilai kearifan lokal dalam pelestarian hutan tropis basah Harau melalui media sosial dianggap paling baik untuk dilakukan di samping tradisi yang sudah ada.

\section{UCAPAN TERIMA KASIH}

Pada kesempatan ini penulis mengucapkan terimakasih kepada semua pihak yang telah banyak membantu dalam penelitian ini

\section{DAFTAR PUSTAKA}

Asrianny, M. Dassir, dan Asrianty, 2012. Pemanfaatan Sumberdaya Hutan di Hutan Lindung Kecamatan Alu, Kabupaten Polman, Propinsi Sulawesi Barat. Jurnal Perennial, 8 (2): 93-98.

Chanan, M., 2011. Potensi Karbon di atas permukaan tanah di Blok Perlindungan Taman Wisata Alam Gunung Baung Pasuruan, Jawa Timur. Jurnal Gamma 6 (2): 101-112.

Gani, E., 2009. Kajian Terhadap Landasan Filosofi Pantun Minangkabau. Jurnal Bahasa \& Seni, 10 (1): 1-10.

Imran, H.A., 2013. Pola Penggunaan Media Komunikasi. Jurnal Studi Komunikasi dan Media, 17 (1): 1-26.

Lampe, M., 2006. Kearifan Lingkungan dalam Wujud Kelembagaan, Kepercayaan/Keyakinan, dan Praktik, Belajar dari Kasus KomunitasKomunitas Nelayan Pesisir dan PulauPulau Sulawesi Selatan. Lokakarya Menggali Nelayan-Nelayan Kearifan Lingkungan di Sulawesi Selatan.
Milles, M. B. and A. M. Huberman, 2007. Analisis Data Kualitatif. UI Press. Jakarta.

Noordwijk, M., F. Agus, D. Suprayogo, K. Hairiah, G. Pasya, B. Verbist dan Farida, 2004. Peranan Agroforestry Dalam Mempertahankan Fungsi Hidrologi Daerah Aliran Sungai (DAS). Agrivita, 26 (1): 1-8.

Salampessy, 2010. Partisipasi Kelompok Masyarakat Dalam Pengelolaan Kawasan (Studi Kasus Di Hutan Lindung Gunung Nona Kota Ambon, Maluku). Jurnal Agroforestry 5 (1): 2024.

Sari, G. H., Dahelmi, dan W. Novarino, 2012 Jenis-Jenis Burung di Kawasan Cagar Alam Lembah Harau Sumatera Barat. Jurnal Biologi Universitas Andalas, 1 (2): 116-122.

Siswadi, T. Taruna, dan H. Purnaweni, 2011. Kearifan Lokal Dalam Melestarikan Mata Air (Studi Kasus di Desa Purwogondo, Kecamatan Boja, Kabupaten Kendal). Jurnal Ilmu Lingkungan, 9 (2): 63-68. 